\title{
From patient-centred ethics to the ethics of a pandemic
}

\author{
Andreas K. Demetriades ${ }^{1}$ (D) \\ Received: 29 November 2020 / Accepted: 1 December 2020 / Published online: 6 January 2021 \\ (C) The Author(s), under exclusive licence to Springer-Verlag GmbH, AT part of Springer Nature 2021, corrected publication 2021
}

The progression of SARS-CoV-2 from outbreak through epidemic to pandemic has generated a wave of medical, social, financial and political consequences. Such profound burden of disease worldwide has brought to the fore ethical challenges that are otherwise experienced only once in a generation. At the operational level, these include resuscitation decisions, critical care triage, allocations of finite resources, testing, protective equipment, prioritisation of treatment and collateral damage; and at the societal level, public-private partnerships, disparities, ethnic minority and social justice, to name but a few. Colleagues across Europe and worldwide have responded admirably to such unprecedented challenges [1-7].

The principles of patient-centred ethics have shifted to public health ethics and the ethics of a pandemic (see Table 1). The focus is no longer the individual patient, but the community and population as a whole. Individual liberty and autonomy give way to relational autonomy and the interdependence of people. The authority vested in the prestige of the medical profession shifts to the authority vested in the policing power of the state and the law. The social good and the avoidance of social harm take priority over an individual patient's beneficence and non-maleficence.

Eijkholt et al. discuss what are our true ethical responsibilities that arise with the scarcity of resources, such as personal protective equipment (PPE), which may put us at the risk of contracting the virus [8]. Is putting ourselves at risk a supererogatory act of moral heroism or an irresponsible action that in itself can lead to a scarcity of healthcare providers?

Even though neurosurgery is a small specialty, it has finite resources and by nature deals with time-dependent and treatment-limiting decisions or actions that are related to the ethics of life preservation. In a survey of comparative activity before and during the first wave of the Covid-19 pandemic across several European centres, $80 \%$ reported they were no longer able to provide neurosurgical care according to legitimate medical needs [9]. This inevitably brought with it moral distress and ethical challenges, such as the prioritisation of patients, triaging and even rationing [4, 9]. These terms, with important semantic differences, may vary in different healthcare systems, relative to their ability to adapt to the huge stress of a pandemic.

As we navigate ourselves through the second wave of the Covid-19 pandemic within the same year, do we have the moral substance, and can we rely on ethical standards plus guidance so as to make professional decisions that will be publicly and socially accountable? Do we have ethical support structures and processes? Do our healthcare structures possess the systemic consistency in regulatory frameworks and in institutional culture to facilitate ethical decision-making?

Andreas K. Demetriades

andreas.demetriades@gmail.com

1 Department of Neurosurgery, Royal Infirmary of Edinburgh, Little France, Edinburgh EH16 4SA, UK 
Table 1 Patient-centred ethics vs. public health ethics

Patient-centred ethics

Focus on the individual

Focus on the treatment of disease

Autonomy in decision-making (of an individual)

Beneficence (doing good for the individual) and non-maleficence (do no harm)

Patient consent

Authority vested in prestige and trustworthiness of the physician and the medical profession

Justice for the individual (allocation of resources to balance for the individual patient both now and in the future)
Public health ethics

Focus on populations and communities

Focus on the prevention of disease

Relational autonomy and interdependence of citizens

Greatest net social good and avoiding social harm

Societal consent through the political process and public engagement Authority vested in the police powers of the state and the law

Social justice and equity (ensuring that the conditions necessary for health are accessible at a fair population level)

Fundamentality (focusing on the primary and underlying causes of disease; and the key requirements for healthy communities)

Community trust (transparency, communication, collaboration, cultural appropriateness, community consent for interventions)

\section{Compliance with ethical standards}

Conflict of interest The author declares that he has no conflict of interest.

\section{References}

1. Borsa S, Bertani G, Pluderi M, Locatelli M (2020) Our darkest hours (being neurosurgeons during the COVID-19 war). Acta Neurochir 162(6):1227-1228. https://doi.org/10.1007/s00701-020-04333-6

2. Gandía-González ML, Sáez-Alegre M, Roda JM (2020) Neurosurgeons on the frontline of COVID-19: no place for surgery? Acta Neurochir (Wien) 162(7):1503-1504. https://doi.org/10.1007/ s00701-020-04390-x Epub 2020 May 8. PMID: 32385639; PMCID: PMC7209762

3. Hulsbergen AFC, Eijkholt MM, Balak N, Brennum J, Bolger C, Bohrer AM, Feldman Z, Holsgrove D, Kitchen N, Mathiesen TI, Moojen WA, Sampron N, Sames M, Sandvik U, Tisell M, Broekman MLD (2020) Ethical triage during the COVID-19 pandemic: a toolkit for neurosurgical resource allocation. Acta Neurochir 16:1-6. https://doi.org/10.1007/s00701-020-04375-w

4. Jean WC, Ironside NT, Sack KD, Felbaum DR, Syed HR (2020) The impact of COVID-19 on neurosurgeons and the strategy for triaging non-emergent operations: a global neurosurgery study. Acta Neurochir 162(6):1229-1240. https://doi.org/10.1007/s00701-020$04342-5$
5. Schaller K (2020) Neurosurgeons in the Corona crisis: striving for remedy and redemption. A message from the president of the EANS. Acta Neurochir 162(6):1217-1219. https://doi.org/10.1007/s00701020-04306-9

6. Tartara F, Cofano F, Zenga F, Boeris D, Garbossa D, Cenzato M (2020) Are we forgetting non-COVID-19-related diseases during lockdown? Acta Neurochir. https://doi.org/10.1007/s00701-02004385-8

7. Zoia C, Bongetta D, Veiceschi P, Cenzato M, Di Meco F, Locatelli D, Boeris D, Fontanella MM (2020) Neurosurgery during the COVID-19 pandemic: update from Lombardy, northern Italy. Acta Neurochir 162(6):1221-1222. https://doi.org/10.1007/s00701-02004305-w

8. Eijkholt M, HULSBERGEN A, MUSKENS I et al Should neurosurgeons continue to work in the absence of personal protective equipment during the COVID-19 era? Acta Neurochir. https://doi.org/10. 1007/s00701-020-04665-3

9. Mathiesen T, Arraez M, Asser T, Balak N, Barazi S, Bernucci C, Bolger C, Broekman MLD, Demetriades AK, Feldman Z, Fontanella MM, Foroglou N, Lafuente J, Maier AD, Meyer B, Niemelä M, Roche PH, Sala F, Samprón N, Sandvik U, Schaller K, Thome C, Thys M, Tisell M, Vajkoczy P, Visocchi M, EANS Ethico-legal committee. (2020) A snapshot of European neurosurgery December 2019 vs. March 2020: just before and during the Covid19 pandemic. Acta Neurochir (Wien) 162(9):2221-2233. https://doi. org/10.1007/s00701-020-04482-8 Epub 2020 Jul 8. PMID: 32642834; PMCID: PMC7343382

Publisher's note Springer Nature remains neutral with regard to jurisdictional claims in published maps and institutional affiliations. 